\title{
The Yoruba News as a Political Tool and Avenue for Cultural Revival
}

\author{
Abidemi Bolarinwa \\ Department of Linguistics and African Languages \\ University of Ibadan, Nigeria \\ aobolarinwa@yahoo.com
}

\begin{abstract}
Newspapers are veritable tools in the dissemination of information. In realization of this, Dénrelé Adétimíkàn Obasá (1879-1945), a poet, reporter, and cultural activist, employed his weekly Yorubá newspaper, The Yorùbá News, he edited from 1924 until his death in 1945 to reflect the essence of the society in all its political and socio-cultural ramifications. Scholarly works abound on the issues of nationalist and political activities of local intelligentsia in colonial Nigeria with little attention devoted to the contributions of these local intellectuals to the growth of literary traditions in indigenous languages. This study therefore examines Obasás contributions to the promotion of the Yoruba' language and indigenous knowledge system through his weekly Yorubá newspaper, The Yoruba News. The study employs a number of selected excerpts from The Yorubá News as its data source. Data were then subjected to content and literary analyses. It is revealed that Obasá, through The Yorüba News, attempts a presentation of pre-colonial life and traditional politics in contrast with colonialism. It is also established that Obasa project the beliefs, values, customs and practices of the Yorubá people in The Yorüá News for sustainability. It is concluded that Obasá was a seasoned journalist and culture activist who employed The Yorubá News as an avenue for archiving and transmitting Yorubá ethos and values. It is recommended that contemporary newspapers should endeavor to reminisce, conserve and preserve Yorubá political and socio-cultural lives for sustainable development.
\end{abstract}




\section{Introduction}

Obasá, a member of the local intelligentsia in colonial Nigeria was a man of many parts. He was a poet, printer, furniture carpenter maker, writer, publisher and newspaper editor. Scholarly works abound on Obasá; which includes Akínyemí (1987, 1995, and 2017), Olábímtán (1975), and Ògúnsínà (1992). Obasa's contribution to the growth of literary tradition in Nigeria indigenous languages are tremendous and worth mentioning. Scholars have worked extensively on Obasá as a poet with little attention paid to his effort in promoting Yorubá language and indigenous knowledge through his weekly Yorubá newspaper - The Yorübá News.

Obasa published the first issue of The Yorubá News, a weekly newspaper that reported local developments in Yorubaland on January 15, 1924. According to Akinyemi (1987), by November 4, 1924, Obasá began an aggressive weekly campaign to promote his first book of poetry in his newspaper. The Yorubá News contributed in no small measure to Obasás achievement and popularity because he advertised and included at least one of his poems in the newspaper on weekly basis to create awareness about his poems so that people can buy it when it is finally published as a book of poetry. Due to Obasás passion and interest in Yorubá language and the cultural practices of his people, he decided to write in Yorubá language and not English within the colonial Yorubá cultural environment (Akínyemí 2017). Thereby preserving the language, tradition, and culture of his people that he thought must not go into oblivion. This paper examines Obasás weekly newspaper, The Yorübá News, with a view to establishing that Obasá employed it as a political tool and avenue for cultural revival. I intend to argue that, Obasá, through the newspaper, presents the pre-colonial life and traditional politics in contrast with colonialism, and projects the Yorubá cultural values and practices.

\section{The Yoruba News as a Political Tool}

Scholars define politics in different ways. Their definitions normally hinge on their different backgrounds, orientations or interest. Weber (1957) posits that politics is striving to share power or striving to influence the distribution of power, either among states or among groups within a state, while Geoffrey (1971) and Duvenger (1976) state that politics is concerned with power and its use in the society. There is competition for benefits, and as such, there will be "winners" and "losers". In other words, politics deals with power. Therefore, politics can be defined as the process whereby some individuals or groups acquire power and exercise that power over others.

Obasá was not indifferent to political matters in The Yorubá News. It is obvious that he participated in the politics of his time, especially as a member 
of a sociocultural organization, Egbé Àgbà ò Tán. He portrayed pre-colonial and colonial politics as they affect the historical past and present, and the sociocultural life of the people. The issues raised by Obasá include: disruption of political structure, (mis)governance and its effects, dispensation of justice and installation of king.

\section{Disruption of Political Structure}

In pre-colonial administration in Yorubáland, the administration of towns and dispensation of justice were under the jurisdiction of the monarch, chiefs and the warlords. Colonization of Africa by European countries was a monumental milestone in the development of Africa. The reason for colonization of Africa was deeply rooted in the ethnocentrism and cultural arrogance of the European people, who regarded anyone different from them as being inferior. In the case of the Africans, because they were not technologically advanced or their achievements were not written and therefore not known to the rest of the world, the Europeans felt that it was their duty to "civilize" and "uplift" the African people. The Europeans always boasted that their incursion into Africa is to share their skills, values, and culture; hoping that someday African people would be able to run their own communities using the tools learned and acquired from them. The European administration was systematic in nature. It was formulated in Nigeria by the colonial governor Lord Fredrick Lugard who was the governor-general of Nigeria at the turn of the twentieth century. Lugard style of administration is known as "indirect rule". The local power structure comprising the monarchs, chiefs, or headmen were identified and then invited, coerced or bribed to become part of the colonial administration. In exchange for becoming part of the colonial structure, a chief was often given protection, a salary, a house, and gifts.

One significant political consequence of indirect rule was that it reinforced separate ethnic identities and stunted the development of a national or colony-wide political consciousness. Inter-ethnic interaction through traditional trade unions or political organizations was secretly restricted and discouraged. The publication of the weekly Yoruba newspaper The Yoruba News by Obasa contributed in no small measure to his success as a local intellectual. Within the colonial Yoruba cultural environment, Obasá preferred the use of Yoruba language in order to address the people in his locality and also to uphold the morale of his community during the colonial era.

Obasá, through The Yorübá News presents the pre-colonial life and traditional politics in contrast with colonialism. Obasa established that through indirect rule the traditional institutions and custom of Africans that the British considered inimical to European civilization were altered. Although the policy 
claimed to respect the traditional political institution and to promote continuity between the traditional rulers and the colonialist, in practice, it undermined their influence and subordinated them to the European resident and district officers. Traditional authorities could not complain because under the British rule, insubordination was a serious offence that could lead to removal from office. Obasá recorded the visit of the Hon. W. Ormsby Gore to Ibadan thus:

The Rt. Hon.W. Ormsby Gorethe Under Secretary of State for the colonies arrived town on Friday 12th, having motored through Ogbomoso. Official circulars were issued to the Baálè and council of Ibadan also Egbé Àgbà-òTán as representing the educated members of the community, to attend at Bere, court on Friday the 12th at $5 \mathrm{pm}$ in honour of the distinguished guest. Long before the appointed time, groups of horse and footmen consisting of the Baále, chiefs and retinue were seen wending their way to Bere, court. The Baálè, chiefs and the assembly rose up as Mr Ormsby Gore alighted from the car accompanied by the Senior Resident. He then enquired whether the Baálè has anything to tell him. The Baálè replied there is nothing in particular as the Senior Resident is taking care of them and looking after the country very well. ("Visit of The Hon. W. Ormsby Gore, M.P." The Yoruba News March 6, 1926).

It is obvious from the excerpt above that the Baálè are no longer in control they are now answerable to the Resident officer, they take orders from the Resident officer, who now has the final say on all issues that pertain to the people in the community. The Baale, under the British rule is no longer in the center of all activities and everything no longer revolves around him.

In a letter to the editor published in the newspaper, the letter writer claimed that the Onitsha people could not hide their feelings about the way they were being tossed around by the so called European Resident officer. Below is their reaction:

In view of the fact that we cannot boast of astute politician who would lead us in the right way, we have remained like sheep without shepherds, and politically we have been crippled to the phantasmagoria depth of nebulosity. Through the mediums of the columns of "Yoruba News" I think it advisable to speak to you by fellow compatriots. ("Onithsa and Civilisation." The Yoruba News March 17, 1925).

One can infer from the above excerpt that the Onitsha people are tired of indirect rule of the British and concluded that The Yoruba News is the right avenue for them to make their grievances known since the newspaper is available to all and sundry. 


\section{(Mis)governance and its Effects}

Due to the contact with the British, the newspaper, in an editorial write-up reported that the Ibadan people also complained about having half-educated chiefs as their leaders. The excerpt below says it all:

The Ibadan chiefs are ever striving simply to benefit themselves and their father's houses without the least thought for the country's welfare. The present condition of affairs portends a very gloomy future for the country. If after 74 years of direct contact with all that makes for enlightenment and progress, Ibadan has in its judicial council only one aged chief and a preponderating number of half-educated children who may attain chieftaincy ranks in the immediate future. Gauging the future by the present it seems we shall only have a set of unlettered and half-educated chiefs ruling the country in the near future to the detriment of the people ("Our Political Situation Bogus." The Yoruba News March 17, 1925).

The Ibadan people opine that it will be a great misfortune for them to be ruled by and with antiquated chiefs and methods. They believed that a chief without knowledge of western civilization, culture and up-to-date methods of government, cannot lead rightly and beneficially or assist the political officers with the best advice for the good of the country. They now conclude that education must be included among the necessary qualifications of every aspirant to a vacant chieftaincy.

A resident of Lagos in a letter to the editor of the newspaper condemns bad leadership among them and asks for leaders who are selfless and who would seek the good of the nation: "Please allow me through the medium of your inspiring journal to call attention of the public to the attitude of so; distant leaders of Lagos community who have utterly failed to mould (sic) our destiny" ("Lagos Leadership." The Yoruba News August 18, 1923). In this excerpt, the writer complained about political leaders who are selfish, unrelenting and misanthropic. The fear of this writer is that if political leaders in question continue in their "useless attempt to plaster the outside of the cup, then the future stability of Nigeria as a nation would be corroded." Therefore, the youths were advised to form clubs, put their heads together, and muster their forces for Nigerians to be hopeful and for her rights and liberties not to be threatened.

\section{Dispensation of Justice}

During the pre-colonial-era, among the Yoruba people, the monarch is regarded with respect and awe, approaching veneration. There is a popular maxim regarding the monarchs as oba alase èkeji orisà (the king, the 
commander and wielder of authority, next to the órisà). Fádípè (1970:205-206) established that due to the powers conferred in the king, or the paramount rulers, the dispute resolution system is rigid. The monarchs enjoyed the freedom of royal governance. The monarch in the pre-colonial era settles all conflicts and his viewpoint on all conflicts has the blessing of an unquestionable truism. Afoláyan (2004) asserts that, "Traditional rulership among the Yorubá people is quite different from modern day kinship. The Yorubá $o b a$ commands both political and spiritual clout in his domain" (266). The traditional institution had its remarkable challenges during the colonial period and it was recorded by Obasá thus:

On the broad question of administration of justice in Nigeria, we most respectively submit that there is necessity for an early repeal of the provincial courts ordinance by allowing representation by counsel in all cases both civil and criminal, particularly in capital offences. Throughout Nigeria there should be one uniform law for all the subjects of His Host Gracious Majesty the King. ("Judiciary." The Yoruba News March 2, 1925).

With the creation of law court during the colonial era, the monarchs now perform secondary roles in the governance of the society. Monarchs are only considered as advisers to the government and are reduced to the level of grassroot leaders. The monarch and his chiefs in the colonial era obey the law put in place under the new political system. They are themselves no more law makers.

\section{Installation of a King}

According to Afoláyan (2004) a king in Yoruba traditional society is selected by his people through a process that includes "progenial elimination and rotation oracular consultation and popular acclamation" (268). Scholars such as Bámgbósé (2001), Oyèdipè (2004), and Alana (2004) reiterate that the king's power had been weakened by the presence of colonial administration, and they were no longer seen as being above the reproach of their people. Obasá reported in his newspaper that: "Shortly after the throne of Oodua was left vacant through the demise of His Highness Adémilúyi Otutu. The Oòni of Ifè, last June, several rival claimants from three of the Ife royal houses had risen to contest the vacancy" (Ife, Affairs: The Yoruba News Aug 19, 1930). We can infer from this short excerpt that the princes had deviated from the ancient laws and customs of Ifẹland which leaves no room for rivalry among the royal houses in the choice of a successor.

According to the ancient law and customs, whenever the throne becomes vacant, it is the duty of the chiefs to commence a meeting where Ifá oracle will be consulted as the final arbiter. Whoever Ifá chooses among the princes of the royal house ascends the throne. This type of selection has helped in no 
small measure to avert evil effect that invariably follow rivalry of royal successions such as ill will, persecution, bitterness and early grave, because the unsuccessful rivals, oppressed with the sense of failure are not likely to feel loyal to the successful claimant, who on the other hand is sure to fear that the others are more influential than to live with him safely in the same town and may ask them to quit the town or persecute them one way or the other. Prevention is better than cure. To avert all these calamities that are likely to befall the princes, they should follow the ancient law and customs that govern the installation of a new king, for peace to reign. There is no gainsaying the fact that Obasa participated actively in the politics of his time. He was the voice of the voiceless; he did not limit his voice to the Yoruba alone but to other ethnic groups as well. He employed The Yorubá News as a tool to presents pre-colonial life and traditional politics in contrast with colonialism.

\section{The Yoruba News as Avenue for Cultural Revival}

Each man is of a common type molded by his culture and society. Culture is essentially inseparable from society. Society is what culture makes and culture is defined by society. Angulu (1975:4-5) asserts that culture and society are arbitrary concepts, which are interwoven and difficult to disentangle. Shehu (2010:21) opines that a society cannot survive without its culture and a culture cannot survive outside a living society. Both are operative and are essential to the community of a people. Individuals are carriers and creators of culture and their roles and fundamental to the society. According to Otite and Ogionwo (1976), no man will be human except as a member of the society. Therefore, the term culture and society are interchangeable. Literature is a weapon of culture; it serves as the echo of cultural reality to observe the aberration in human behavior and governance from generation to generation. The Yorubá people interpret, express and transmit their culture through literature. Isola (2010) captures the significant roles of literature in human culture when he says: "In traditional Africa society, the whole fabric of living was beautifully patterned with the thread and colour of literature. The process of socialization from cradle to the grave was eased and made effective through the use of literature" (67).

A literary artiste is a product of his society and upbringing (Fólórunsó, 1998, Bámidélé 2000, Bámgbósé 2007, and Láyiwolá 2010). Obasa, being a culture

activist projects Yorubá beliefs, values, and cultural practices in The Yorübá News thereby archiving and transmitting Yorubá ethos and values. The cultural issues that Obasa discussed extensively in The Yoruba News are: Beauty, Agriculture, traditional Medicine, Traditional African Festival and Traditional African Marriage 


\section{Beauty}

Before the advent of Europeans on Africa soil, Africans used various art forms for bodily decoration and ethnic identification in periods of inter-ethnic strife and cooperation, celebration of achievement, competitions and expressing of beliefs in love, relationship with others and with supernatural forces (Bewaji 2003:102). Many of these artistic expressions are simply beautification of the self. While some are devoted to specific occasions and functions, others are for the work-a-day situations and as such are part of daily dressing. In traditional African society when it comes to facial dressing or beautification osun and tiroo are the facial make-up that people grew up to know. With the advent of civilization people change to powder but Obasa vehemently opposed it thus:

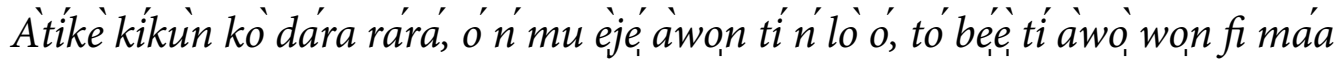

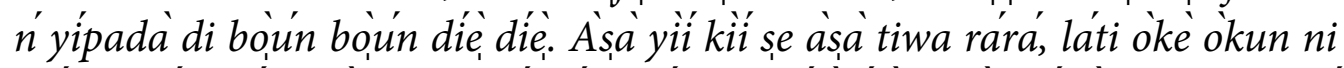
wón ti kó wá. Osùn ni a máa n' fi kún ara téletélè. Osùn kíkùn fun tomodé tàgbà dára púpò toripé a máa jé ki ara jolò. A si rò pé ó kúkú ye kí a fi owó mú àsà ilé wa ju kí a máa sáré lo bá àwon ará ilè mi dá àsà ti won "A'tike" in The Yoruba News Aug 5-12 1930)

Rubbing of power is not good at all, it drained the blood of the users to the extent that their skin is discolored. This act is not part of our culture, it was imported from abroad. We rub our body with osun initially. Rubbing of osun by young and old is very good because it smoothens the skin. We are of the opinion that we should hold fast to our culture instead of running to imbibe other people's culture.

Obasá in The Yorübá News admonished his people to appreciate what belongs to them and of great benefit such as osun and do away with powder (atikè) that is foreign and do a lot of havoc to human body.

\section{Agriculture}

Agriculture was the mainstay of the economy of the Yoruba people before the advent of the western culture. Each family depended on the male members for the clearing of the fields, planting of crops, as well as harvesting. Wives accompanied their husband to the farm. They are also responsible for the selling of the farm produce. Due to the fact that majority of Yoruba people are farmers they have food in abundance. Colonization brought about rapid changes in Yorubá economy. With the introduction of western education, farming was no longer the main occupation of the Yoruba people. Rural urban migration in search of education and white-collar jobs adversely affected agriculture. Obasá 
in The Yoruba News encouraged people to go back to agriculture so that we can have food in abundance and to put an end to importation of food. Below his Obasás advice:

Ki a ma ba pada lo roko ni a fi n'so pé a n'kowe; àkòwé kî́ tún roko mo e. ko ha ri pé ékó àbò ni a n kó, laîsi é èóti oko ríro nibè. Nitorí náa a be àwon olukó wa ni ilé-èkó wa kí wón túbò tera mó oko ríro àti ohun ògbìn, Agriculture. A kiyesí ni odún tó kojá pé àwon Tachers láti orisirisisi Ekún wá si Agriculture Department ni İbàdàn láti wá lo bí osù mèsán láti fi kó, isé ohun ògbin, àti pé léyin ti a kó won tán, wón padà si enu isé won láti máa kóàwon omo iléeèkó agbègbè ibití won ti rán won wá. Eyé wú wa lórí púpo ó si dájú pé ko si omo tí o mo èkó ohun ògbin dada tí ki yoò rò lórù láti padà sí ese áarò bi ti akơwé office ko bá sese mó. Ní agbo ilé ayé a ni láti kó èkó tó jinlé nipa ohun ògbin àti isé oko, ki ó bá le rò wá lórun léhin olla ("Kókóró Ilé-Aye”" The Yoruba' News of Sept 13, 1938).

In our effort not to go back to agriculture we say we are literate, a literate person does not cultivate again. Can't you see that education is not complete without agriculture. Therefore, we beseech our teachers in schools to pay more attention to agriculture, we observe last year that teachers from different districts visited the Department of Agriculture in Ibadan and spent nine months to learn the rudiments of agriculture. After they've been taught, they returned to their working places to teach students in their districts where they were being sent for training. This is highly impressive, and we are sure that there are no students that know the rudiments of agriculture that will not find it easy to go back to the beginning if working in an office becomes impossible. In this world, we have to learn about planting and agriculture. So as to have a better future.

Obasa through The Yoruba News encouraged all and sundry to go back to agriculture because it is the only profession that does not fail when others fail.

Also in "Ifá Aditi" (The Yoruba News of Oct 6 1931), Obasá writes extensively about palm tree and palm fruits that are processed into palm oil and used in preparation of different kinds of food, and also, serves as a source of income for the family because it is sometimes exported. Obasa therefore through The Yoruba News projects Yorubá cultural practices to the outside world and also revive some aspects of the Yorubá culture that are going into oblivion. 


\section{Traditional Medicine}

The use of herbs and plants called ewe or egbò is very important and central to the healing system among the Yorubá. Herbs are picked for medicinal and spiritual empowering purposes. The herbs are gathered by priests, herbalists or those who know what to do with herbs in Yorubaland. In spite of the enormous pressure of western civilization, the presence and use of traditional methods of healing is undeniable in Yorubá society. Plants are generally beneficial to man, depending on the experience of the user and what each plant is used for. Parts of plant, or a whole plant can be used in the treatment of disease like yellow fever, dysentery, high blood pressure, fibroid, measles, malaria-fever, rheumatism, ulcer and other (Fagbeku, 2008:13).

Obasa had positive things to say about the traditional herbal medicine in almost all the issues of The Yoruba News. There is even a regular column in the newspaper that Obasá titled "Yoruba Physics" that was dedicated for writeups on Yorubá traditional medicine. For instance, Obasá published an essay on preventive and healing treatments in the March 2, 1926 and March 16, 1926 editions of The Yoruba News. He discussed extensively on herbal medicine and established that Yoruba traditional medicine does not only heal the physical ailment, but that it also ensures the healing of spiritual part of the patient. Obasá, though the essay corroborates the view of Oyelakin (2009:75) that African medicine performs three distinct functions: getting rid of the symptoms, identifying and removing the causes of the illness and maintaining a holistic balance. Traditional medicines were also advertised in editions of The Yoruba News thereby creating awareness for people to utilize alternative medicine to cure whatever disease that they are suffering from. Some of the advertised traditional medicine in The Yorübá News include: Fertility herbs for male, White Golden Female Tonic, and white Golden Male Tonic. Obasa through his weekly newspapers succeeded in establishing that Yoruba traditional medicine is efficient and beneficial to mankind.

\section{Traditional African Festival}

Act of worship among the Yoruba is a true reflection of the sociological context of their locality. Olódumare occupies a very high status as the king of the heavens and earth. He has the divinities who emanated from Him and who are his messengers or ministers in His theocratic government of the world. The Yoruba belief system is built on the firm assumption in the existence of God who is the Creator and Determiner of life of man. The Yorubá also commemorate the divinities who are believed to be emissaries of God in His theocratic government of the universe through traditional festivals. People partake in various traditional festivals within their different communities and 
localities for protection and security in times of crisis or as their family heritage. However, colonization and civilization have affected traditional African festivals and people no longer want to be associated with these traditional religious festivals again. Anybody that does so is regarded as an unbeliever and seen as worshipping idols.

In realization of this fact, Obasa through The Yorubá News document some traditional African Festivals for generation unborn to read and for preservation. In the Oct 27, 1934 edition of The Yorubá News, Obasa discussed the celebration of Sànó festival thus:

Àwon onisiangó bèrè odún won ní Wednesday Oct 21. Áwon ará oko diè tí ó sì ku nidii a n' bo Sàngó wá silé, nse ni wón n' gbá riyè lóde. "OOdún Sàngo" in The Yoruba' News of Oct 27, 1934).

The Sango worshippers started their celebration on Wednesday Oct 21. The few people from the town that are still worshipping Sàngo returned home, they were just moving about on the street.

Obasá also documents Olojó and Edì festivals that are celebrated among the Ife, people even till date. The accounts of the two festivals are given below:

The reports of the two important National Festivals in Ife, will no doubt, interest the readers. During the week-ending September 10th town was flooded with large numbers of people who came mainly to celebrate Olojó, festival (The Yoruba News of November 24, 1931).

On November 3, 1931, the people streamed to the town from every direction, the districts, towards villages and hamlets in order to grace the celebration of Edi festival in great number (The Yoruba News of November 24, 1931).

Okebàdan festival that is one of the important festivals celebrated annually in Ibadan land was also showcase by Obasá in The Yorubá News: "Wón se odún Òkèbàdàn ni ijeta bí wón ti máa né se e. Enikéni kò dá iná lojú òpópó títi ile fi sú” - They celebrated Okebadan festival three days ago as usual. Nobody cooked throughout the day. ("Okèbàdàn" in The Yorubá News of March 3, 1936).

Obasa through The Yorübá News documented some traditional festivals in Yorubá land, thereby encouraging the revival of the Yorubá cultural heritage. 


\section{Traditional African Marriage}

Marriage is seen as a strong bond of love, unity, and togetherness among couples in Yorubáland. It is coming together of a man and a woman in order to start a new family and a social obligation that must be accomplished. Among the Yorubá people, marriage is considered very crucial and desirable. Marriage is very special in most African traditions. The parents of each of the prospective partners play important roles. Parents of would-be couple inquired about the family of the other prospective partner, their health history in relation to mental health and other serious ailments. After the inquiries, and if both families are satisfied with the outcome of their findings, formal espousal would be announced. The family of the would-be groom will send gifts to the family of the bride-to-be bride in appreciation and this marks the sealing of the marriage proposal.

Obasá comments extensively about marriage in traditional Yorủbá society in his newspaper. He asserts that marriage in traditional Yoruba society is good: “Ásà ìgbeyàwó ní ilè wa dára, ó lólá, ó sì níyi púpò" - Marriage in our society is good, it is honorable and respected ("İyawo Odún" in The Yorüba' News of Oct 13, 1931).

Obasá also discussed the relationship between husband and wives in the traditional Yorubá society thus:

Aiye dára ni igboro ỉbàdàn ní àkóko tí a n' wí yî́, oko níyi lówó aya, aya sì níyi lówó oko rè, ko sí gbón mi sí, omi ko tó o bi ti aiyé isisiyi, beni àwon obinrin ki i si ko oko, won to be nígbà náà. ("Iyàwó Odún" in The Yorubá News of Oct 13, 1931).

Life was good in Ibadan metropolis that time that we are talking about, wives respect their husbands, husbands also respect their wives, there is few conflict compare to this period, also women hardly separate with their husbands.

Due to increase in number of broken homes and the adverse effect this is having on the children, Obasa argued that there is the need to curb the growing incidences of divorce so that the children that are leaders of tomorrow will not end up as criminals. Obasa frowns at the way young adults get married without the consent of their parents. This, according to Obasa, is contrary to Yorubá traditional culture.

Bì àwon obinrin ti n fé, lo àsà "Emi ni mo ni ara mi" yì sí oko, obí, àti ebí won, bế, náa ni àwon okùnrin papa n'kó àsáa àibikità fún àna, obia àti ebí won 
dé ibi pé, ko tún si en nikan tí wón bòwơ fún mó. ("İyàwó odún” in The Yorùbá News of Oct 13, 1931).

The way women get accustomed to "I owned myself" to husband, parent and their families, in the same vein men also care less about their in-laws, parents and their families to the extent that, they no longer respect anyone.

In the Yoruba traditional society, family members are involved in the process of marriage and they make provision for solving family feuds and fostering harmony. But Obasá condemned the new trend whereby couples get married without the consent of their parents and family members. This makes their marriage the exclusive preserve of the couples only. According to Fádipè (1970:68), this is called informal extra-legal marriage by the mutual consent of the two principal parties alone. So, rather than seek advice and resolve issues within the extended family when it is highly necessary they prefer to go to court of law for divorce. Obasá employed The Yorubá News as avenue in shaping and correcting the ills in marriage institution thereby finding last solution to the cultural problem facing the society.

\section{Conclusion}

This essay examines Obasá's weekly newspaper, The Yorübá News with a view to showcase his effort in promoting Yorubá language and indigenous knowledge. A thematic analysis of The Yoruba News reveals that Obasa as the editor employed the newspaper as a political tool, to reveal the erosion of power from the kings and chiefs by the Europeans, and how dispensation of justice was taken away from the king. The British colonial government exerted a lot of impact that altered much of the traditional Yoruba culture. The cultural issues that Obasá discussed in The Yorubá News are: beauty, agriculture, traditional medicine, traditional African festival and traditional African marriage. Obasá encouraged Yorubá people to appreciate what they have, and stop using cosmetics that may cause them a lot of havoc. He also admonished his readers to go back to agriculture because it is the only profession that cannot fail. He also established that traditional medicines are efficient and beneficial to mankind. Obasá through The Yorubá News enlighten people on the essence of traditional festival. Obasá also made known his love and appreciation of traditional marriage, he argues that there is need to curb the growing incidences of divorce so that the children that are leaders of tomorrow will not end up as criminals.

There is no gainsaying the fact that Obasá employed The Yorubá News as a political tool and avenue for cultural revival because he encouraged and 
revived Yorubá cultural heritage through the newspaper so as to preserve and protect them for enhanced understanding, appreciation and sustainable development.

\section{References}

Adémúwàgún, Z. African Therapeutic Systems. Los Angeles: Crossroads Press, 1979.

Afigbo, A.E. The warrant Chiefs Indirect Rule in Southeastern Nigeria. 18911929. London: Longman, 1972.

Afoláyan, M.O. and Afoláyan, P.O. (2004) "Obas in Contemporary Politics." In

Nike S. Lawal et al (eds.) Understanding Yoruba Life and Culture. Trenton: Africa World Press.

Akínyemí, A. “Àkoónú Ewì Àpilẹ̀o Obasá." In Sémínà Nì İrántí J.S.A. Odujinmin. 205-282 Ode-Remo: Odujinrin Publishing Company, 1995.

Akínyẹmí, A. "Adénrelé Adéétimíkán Obasa (1927-1945): Akéwì Alárojinle’" Unpublished M.A. Thesis, University of Ife, Nigeria, 1987.

Akínyemí, A. "D.A. Obasá (1979-1945): A Poet, Culture Activist and Local Intellectual in Colonial Nigeria. Africa. 87.1, (2017): 1-15.

Alana, O. “Traditional Religion.” In Nike S. Lawal et al (eds.). Understanding Yorubá Life and Culture. 65-80. Trenton: Africa World Press, 2004.

Angulu, O. The Social Anthropology in Africa: An Introduction. London: Heinemann Educational Books Nigeria Plc, 1975.

Bámidélé, O. Literature and Sociology. Ibadan: Stirling-Horden Publishers (Nig) Ltd, 2000.

Bámgbosé, A. "Language, Culture and the African Renaissance." In E.O. Olúkojú (ed). A golden Heritage: Essays in Celebration of St. Andrew's College, Oyó. 3-22. İbàdàn: Heinemann Educational Books Nigeria Plc, 2001.

Bámgbósé, A. The Novels of Fagunwa. Ibadan: Nelson Publishers Ltd, 2007. (New Edition).

Barber, K. "Why Do We Need a Sociology of Literature." Paper presented at the Sociology of Literature Seminar, University of Ife, Nigeria, 1978.

Béwají, J.A. Beauty and culture: Perspective in Black Aesthetics. Ibadan: Spectrum Books Limited, 2003.

Dasylva, A.O. "The Beauty of the Ugly: A Perspective on Albert Canous and the Absurd." Obitun: Journal of Humanity. 1.1 (1995): 81-90.

Duvenger, M. The Study of Politics. Hong Kong: Thomas and Cromel Company Inc, 1976.

Fádipe, N.A. The Sociology of the Yoruba. Ibadan: Ibadan, University Press Ltd, 1970. 
Fágbekú, P. “Traditional Medicine. The Arts, Ways and Practice in Outlines and Pictures of Medicinal Plants from Nigeria." In T. Odugbemi (ed.) 1525. Lagos: University of Lagos Press, 2008.

Geoffrey, Peter. (Ed.). A Dictionary of Political Analysis. London: Longman, 1971.

Imoagene, Oshoma. Peoples of the Cross River and The Eastern Delta. Ibadan: New Era Publishers, 1990.

İsòlá, A. Making culture Memorable: Essays on Language, Culture and Development. Ibadan. DB Martoy Books, 2010.

Ita Sadowsky J. Imperial Bellam: Institutions of Madnesss in Colonial South West Nigeria. California: University of California Press, 1999.

Miall, Hugh, Oliver Ramsbotham, and Tom Woodhouse Contemporary Conflict Resolution: The Prevention, Management and Transformation of Deadly Conflicts. Cambridge: Polity Press, 1999.

Ogúnsina, O. The Development of the Yoruba Novels. Ibadan: Gospel Faith Mission Press, 1992.

Ojó, I.F. "Cultural Development as a Panacea for Nigeria's Dwindling Economic Realities." Journal of the School of Languages 5. (2010): 247-249.

Olábimítán, A. "Language and Style in Obasa’s Poetry." In Wande Abimbola (ed.) Yoruba Oral Tradition 1031-1069, Ife: African Languages, Series No $1,1975$.

Otite, O. and Ogion, W. An Introduction to Sociological Studies. 2nd Edition. Heinemann Educational Books Plc, 1976.

Oyedípè, A. "Changes in the Traditional Family System. In Nike S. Lawal et al (eds). Understanding Yorübá Life and Culture. 247-257. Trenton N.J: Africa World Press INC, 2004

Oyelákin, R. "Yoruba Traditional Medicine and the Challenge of Integration" The Journal of Pan African Studies. 3.3 (2009). 73-90.

Roberts, F.O.N. “Traditional Rulers, Governance and the Postcolonial State. In Olufemi Vaugham (ed.) Indigenous Political Structures and Governance in Nigeria. 13-47. Ibadan: Bookcraft Ltd, 2004.

Sheffield, R. "What Do We Need to Know About Conflict." In James E. White and Robert L Sheffield (eds.), Equipping Deacons to Confront Conflict.1-21. Nashville: Convention Press, 1987.

Shehu, F.S. "Culture Orthodoxy in Selected Novels of Yorubá Expression" Unpublished Ph.D. Thesis, Department of Linguistics and African Languages, Ibadan, Nigeria, 2010.

Weber, Max. The Theory of Social and Economic Organisation. Translated and edited by A.H. Handerson and Talcot Parsons Glencoe III. The Free Press, 1957.

Williams, F. Culture and Society. New York: Penguin, 1958. 
Womack, K. "Introduction: Theorising Culture, Reading Ourselves." In J. Wolfreys (ed.) Literary Theories: A Reader and Guide. 593-603. New York: University Press, 1999. 